\title{
EFEKTIVITAS PENERAPAN PICTURE EXCHANGE COMMUNICATION SYSTEM (PECS) TERHADAP KEMAMPUAN BERBICARA EKSPRESIF PADA ANAK DOWN SYNDROME
}

\section{THE EFFECTIVENESS OF APPLYING PICTURE EXCHANGE COMMUNICATION SYSTEM (PECS) TO EXPRESSIVE SPEECH ABILITY IN DOWN SYNDROME CHILDREN}

\author{
Nurlianti Safira1), Eva Meizara Puspita Dewi2), Harlina Hamid ${ }^{3)}$ \\ 1,2,3)Fakultas Psikologi, Universitas Negeri Makassar, Indonesia \\ nurliantisafira07@gmail.com ${ }^{1}$, eva.meizara@unm.ac.id ${ }^{2}$ ), harlina.hamid@unm.ac.id ${ }^{3)}$
}

\begin{abstract}
Abstrak
Kemampuan berbicara ekspresif anak down syndrome sangat terbatas karena komunikasi nonverbal yang terlalu aktif. Picture Exchange Communication System (PECS) merupakan salah satu metode yang dapat digunakan untuk membantu meningkatkan kemampuan berbicara ekspresif. Penelitian ini bertujuan untuk mengetahui efektivitas penggunaan penerapan Picture Exchange Communication System (PECS) terhadap kemampuan berbicara ekspresif anak down syndrome. Partisipan dalam penelitian ini berjumlah satu orang anak down syndrome dengan karakteristik memiliki usia 7-12 tahun, dan kemampuan menyebutkan kosa kata di bawah lima. Penelitian ini menggunakan singlecase experimental design pola A-B-A dengan teknik pengumpulan data observasi dan dokumentasi. Teknik analisis data menggunakan analisis deskriptif kualitatif dan uji hipotesis dilakukan dengan membandingkan hasil pretest dan posttest. Hasil uji hipotesis menunjukkan bahwa penerapan Pictute Exchange Communication System (PECS) efektif meningkatkan kemampuan berbicara ekspresif responden, yaitu bertambah enam jumlah kosakata yang mampu diucapkan setelah 17 kali diberikan PECS. Penelitian ini menjadi alternatif bagi orang tua dan guru dalam meningkatkan kemampuan berbicara ekspresif dengan menggunakan PECS dalam kehidupan sehari-hari.
\end{abstract}

Kata kunci: down syndrome, kemampuan berbicara ekspresif, PECS

\begin{abstract}
The ability to speak expressively down syndrome children is very limited due to overactive nonverbal communication. Picture Exchange Communication System (PECS) is one of the methods that can be used to help improve expressive speech skills. This study aims to determine the effectiveness of the use of Picture Exchange Communication System (PECS) on the expressive speech ability of down syndrome children. Participants in this study numbered one down syndrome child with characteristics aged 7-12 years, and the ability to mention vocabulary under five. This study used a single case experimental design with A-B-A pattern with observation and documentation data techniques. The data analysis technique used qualitative descriptive analysis and hypothesis testing was done by comparing the results of the pretest and posttest. Hypothetical test results showed that the application of Picture Exchange Communication System (PECS) effectively improved the respondent's expressive speech ability, which increased the number of vocabulary that was able to be spoken after 17 times given by PECS. This study is an alternative for parents and teachers in improving expressive speaking skills by using PECS in daily activity.
\end{abstract}

Keywords: down syndrome, expressive speech ability, PECS 
How to Cite: Safira, N., Dewi, E. M. P., \& Hamid, H. (2021). Efektivitas penerapan Picture Exchange Communication System (PECS) terhadap kemampuan berbicara ekspresif pada anak down syndrome. Al asma: Journal of Islamic Education, 3(1), 50-63.

\section{PENDAHULUAN}

Down syndrome merupakan gangguan perkembangan yang menyebabkan anak memiliki abnormalitas secara fisik dan mental. Wardah (2019) mengemukakan bahwa menurut World Health Organization (WHO) terdapat satu kejadian down syndrome setiap 1.000 kelahiran di seluruh dunia. Irwanto, Wicaksono, Ariefa, dan Samosir (2019) mengemukakan bahwa frekuensi anak dengan down syndrome di Indonesia 1 dalam 600 kelahiran hidup. Indonesia memiliki prevalensi anak 24 sampai 59 bulan dengan kasus down syndrome sebesar $0,12 \%$ pada tahun 2010, kemudian terjadi peningkatan 0,13\% pada tahun 2013, dan meningkat menjadi 0,21\% pada tahun 2018.

Indah (2017) mengemukakan bahwa anak down syndrome memiliki jumlah kromosom 21 yang berlebih. Irwanto, Wicaksono, Ariefa, dan Samosir (2019) mengemukakan bahwa jumlah kromosom yang berlebih menyebabkan gangguan perkembangan. Gangguan perkembangan yang dialami anak down syndrome menyebabkan banyak keterlambatan, salah satunya keterlambatan berbicara ekspresif. Kemampuan berbicara ekspresif merupakan kecakapan, kekuatan dan kesanggupan mengucapkan bunyi artikulasi kata dengan tujuan mengekspresikan, menyampaikan pikiran, perasaan, dan gagasan menggunakan bahasa secara lisan sehingga dapat dipahami.

Indah (2017) mengemukakan bahwa anak down syndrome hanya memiliki kosakata yang sedikit untuk diucapkan, cenderung pendek, dan telegrafis (tanpa imbuhan dan kata sambung). Kumin (2003) mengemukakan bahwa anak down syndrome dapat mengembangkan kata pertama di usia 24 bulan, sedangkan anak normal sudah mampu menguasai 200-300 kata. Hasil penelitian yang dilakukan oleh Marder dan Ní Cholmáin, (2006) mengemukakan bahwa keterlambatan anak down syndrome berbicara menyebabkan anak lebih sering menggunakan tanda, isyarat, dan ekspresi wajah untuk berkomunikasi dengan perawat atau orang tua. Hal ini sejalan dengan hasil obervasi dan wawancara yang dilakukan oleh peneliti dilapangan dengan anak down syndrome, yaitu responden RA terlalu aktif menggunakan bahasa nonverbal, bubbling, dan hanya mampu mengucapkan lima kata (mama, ummi, kaka, kiki, dan ayah). Selain itu, RA biasanya akan menjadi marah ketika orang tua tidak memahami apa yang dimaksud dan memilih membiarkan.

Anak down syndrome memerlukan alat bantu atau metode khusus dalam mengembangkan kemampuan berbicara ekspresif agar dapat berkomunikasi sehingga orang tua dan guru mampu memahami keinginan anak. Kumin (2003) mengemukakan bahwa salah satu sistem komunikasi yang dapat membantu anak down syndrome berkomunikasi, yaitu Picture Exchange Communication System (PECS). Pemberian PECS pada diagnosa anak down syndrome dan autis membantu dalam mengajarkan keinginan dan dorongan komunikatif. Penelitian yang dilakukan oleh Rosalina (2017) terhadap satu siswa di SLB Pembina Tingkat Provinsi Sulawesi Selatan menggunakan PECS terhadap komunikasi verbal. Hasil penelitian menunjukkan bahwa sebelum diberikan PECS siswa hanya mampu mengenal buku, pensil, tas atau sebanyak $20 \%$ dan pada saat pemberian 
sepuluh kali intervensi menunjukkan nilai rata-rata 74,5\% atau siswa mampu mengenal 11 objek.

Penelitian yang dilakukan Heryati dan Ratnengsih (2017) menggunakan PECS terhadap kemampuan komunikasi pada dua siswa autis di SLB C Asih Manunggal menunjukkan hasil yang signifikan. Kemampuan kominikasi anak autis meningkat terlihat dari mean level responden pertama menunjukkan kemampuan komunikasi pada kondisi baseline sebesar 4,7\% kemudian ketika pemberian PECS mengalami peningkatan sebesar 6,5\%. Responden kedua pada kondisi baseline sebesar 5,7\% kemudian setelah pemberian PECS mengalami peningkatan sebesar $11 \%$. Hasil penelitian tersebut sejalan dengan penelitian Vistasari dan Patria (2019) dengan menggunakan dua responden anak autis untuk melihat kemampuan berbicara terstruktur. Responden yang diberikan PECS mengalami peningkatan kemampuan berbicara dengan struktur menggunakan dua pola, yaitu SP (Subkjek-Predikat) dan PO (Predikat-Objek).

Heryati dan Ratnengsih (2017) mengemukakan bahwa PECS merupakan metode yang digunakan untuk melatih berkomunikasi menggunakan simbol visual. Samosir (2019) mengemukakan bahwa anak down syndrome dapat belajar kata-kata baru secara cepat dengan menggunakan prototype dari masing-masing konsep. Anak down syndrome lebih sulit memproduksi kata kerja untuk aktivitas baru dibandingkan kata benda dengan objek yang nyata.

Berdasarkan latar belakang yang telah diuraikan, keterlambatan kemampuan berbicara ekspresif anak down syndrome dapat dibantu dengan menggunakan metode penerapan Picture Exchange Communication System (PECS). Namun, penemuan beberapa hasil penelitian menunjukkan penggunaan PECS hanya diberikan kepada anak autis dan sangat minim diberikan ke anak down syndrome di Indonesia terkhususnya di Kota Makassar sehingga tujuan dari penelitian ini yaitu untuk mengetahui efektivitas penerapan Picture Exchange Communication System (PECS) terhadap kemampuan berbicara ekspresif pada anak down syndrome. Adapun hipotesis yang diajukan, yaitu penerapan Pictute Exchange Communication System (PECS) efektif meningkatkan kemampuan berbicara ekspresif pada anak down syndrome, yaitu terjadi peningkatan kemampuan berbicara ekspresif setelah diberikan PECS dibandingkan dengan sebelum diberikan.

\section{METODE PENELITIAN}

Penelitian ini menggunakan pendekatan eksperimental kasus tunggal atau singlecase experimental design. Latipun (2008) mengemukakan bahwa pendekatan eksperimen kasus tunggal merupakan sebuah desain penelitian yang mengevaluasi efek suatu perlakuan atau intervensi dengan kasus tunggal. Kasus tunggal dapat berupa beberapa responden dalam satu kelompok atau satu responden yang diteliti tunggal. Pola desain single case design yang digunakan dalam penelitian, yaitu desain A-B-A.

Sunanto, Takeuchi, dan Nakata (2005) mengemukakan bahwa desain A-B-A menunjukkan hubungan sebab akibat antara variabel terikat dan variabel bebas yang lebih kuat. Adapun pola dengan desain A-B-A, yaitu A-1 (baseline) merupakan kondisi di mana pengukuran perilaku sasaran dilakukan pada keadaan natural sebelum diberikan intervensi apapun. Pengukuran pada fase ini dilakukan dengan mengukur kemampuan awal anak dalam kemampuan berbicara. B (intervensi) merupakan gambaran mengenai 
kemampuan berbicara ekspresif selama diberikan PECS atau perlakuan secara berulangulang dengan melihat hasil pada saat intervensi. Pada tahap ini anak diberikan perlakuan menggunakn gambar-gambar dari PECS dari fase I sampai IV hingga didapatkan data yang stabil. A-2 merupakan pengulangan kondisi baseline A-1 sebagai evaluasi intervensi yang diberikan berpengaruh pada anak down syndrome.

Penelitian ini melakukan pengukuran PECS dengan empat fase, yaitu Fase I- IV secara berulang untuk mempelajari seberapa banyak perubahan yang terjadi pada variabel terikat dari hari ke hari. Penelitian dilaksanakan dari tanggal 17 September - 26 Oktober 2020 sebanyak 17 kali pertemuan dengan waktu setiap sesi maksimal 30 menit. Pertama, responden melakukan diskriminasi mainan yang akan digunakan selama proses pemberian PECS. Responden diperlihatkan dengan berbagai macam mainan yang ada di klinik Rumah Mentari. Enam mainan yang disukai oleh responden digunakan sebagai reinforcement dan satu mainan yang tidak disukai digunakan untuk diskriminasi gambar di fase III.

Kartu PECS yang digunakan dalam proses penelitian menggunakan foto asli mainan yang disukai responden setelah melakukan diskriminasi mainan. Samosir (2019) mengemukakan bahwa anak down syndrome dapat belajar kata-kata baru secara cepat dengan menggunakan prototype. Irwanto, Wicaksono, Ariefa, dan Samosir (2019) mengemukakan bahwa anak down syndrome lebih sulit memproduksi kata kerja untuk suatu aktivitas dibandingkan kata benda dengan objek yang nyata.

Kedua, responden diukur kemampuan berbicara ekspresif dengan diberikan pretest menggunakan instrumen lembar observasi dari klinik Rumah Mentari. Tujuan diberikan pretest, yaitu mengetahui kemampuan responden tentang kartu PECS yang telah disediakan menggunakan lembar pretest dan kemampuan responden mengucapkan kartu gambar yang telah disediakan sebelum pemberian PECS. Ketiga, responden diberikan perlakuan PECS.

Tabel 1. Skema Desain Eksperimen

\begin{tabular}{cccc}
\hline Kelompok & Pretest & Perlakuan & Posttest \\
\hline Eksperimen & $Y_{\text {Pre }}$ & $\mathrm{X}$ & Yost \\
\hline
\end{tabular}

Responden dalam penelitian ini RA seorang siswa kelas 3 SD SLB Negeri 1 Makassar yang memenuhi kriteria, yaitu anak dengan gangguan down syndrome, memiliki rentang usia 7-12, kemampuan dalam berbicara ekspresif yang lambat dengan menyebutkan kosa kata di bawah lima kata, bubbling serta pengucapan kata yang tidak jelas, merupakan siswa SLB Negeri 1 Makassar, dan bersedia mengikuti penelitian dengan menandatangani informed consent.

Teknik pengumpulan data menggunakan teknik observasi dan dokumentasi. Sugiyono (2016) mengemukakan bahwa observasi merupakan proses melihat, mengamati, mencermati, dan merekam perilaku secara sistematis dalam penelitian. Creswell (2014) mengemukakan bahwa observasi merupakan teknik dalam pengumpulan data di mana peneliti merekam atau mencatat semua aktivitas yang terjadi selama proses penelitian. Teknik observasi dalam penelitian ini dilakukan secara sistematis untuk melihat perkembangan kemampuan berbicara ekspresif selama proses penelitian. Responden akan diamati setiap pemberian perlakuan PECS oleh dua observer untuk mencatat setiap 
perilaku yang muncul pada percobaan satu sampai 10 dan melihat perkembangan yang terjadi.

Creswell (2014) mengemukakan bahwa metode dokumentasi merupakan metode yang dimulai dengan menghimpun, memilih-milih, dan mengategorikan dokumen sesuai dengan tujuan penelitian, kemudian mulai menerangkan, mencatat, dan menafsirkan. Dokumentasi yang dapat digunakan dalam penelitian ini berupa foto yang bertujuan sebagai data observasi dalam proses pemberian PECS. Instrumen yang digunakan dalam penelitian, yaitu lembar observasi. Lembar observasi merupakan acuan dalam pengamatan untuk mengetahui peningkatan kemampuan berbicara. Lembar observasi yang digunakan berdasarkan kartu gambar yang dipilih responden sebagai reinforcement selama proses penelitian.

Teknik analisis data menggunakan teknik analisis deskriptif kualitatif. Mukhtar (2013) mengemukakan bahwa teknik analisis deskriptif kualitatif bertujuan untuk mendeskripsikan seluruh keadaan yang terjadi selama proses penelitian. Uji hipotesis dilakukan dengan membandingkan hasil pretest dan posttest responden untuk mengetahui efektivitas penerapan PECS terhadap kemampuan berbicara ekspresif berdasarkan lembar observasi.

\section{HASIL DAN PEMBAHASAN}

Hasil

Tabel 2. Hasil Pretest dan Posttest

\begin{tabular}{llccc}
\hline No. & \multicolumn{2}{c}{$\begin{array}{c}\text { Pretest } \\
\text { Kenda }\end{array}$} & Tidak & \multicolumn{2}{c}{$\begin{array}{c}\text { Posttest } \\
\text { Kemampuan Berbicara } \\
\text { Jidak }\end{array}$} & Jelas \\
\hline 1 & Setir & $\checkmark$ & & $\checkmark$ \\
2 & Truk & $\checkmark$ & & $\checkmark$ \\
3 & Buah & $\checkmark$ & & $\checkmark$ \\
4 & Hp & $\checkmark$ & & $\checkmark$ \\
5 & Kasir & $\checkmark$ & $\checkmark$ & $\checkmark$ \\
6 & Pemadam & $\checkmark$ & & $\checkmark$ \\
7 & Laba-laba & $\checkmark$ & & \\
\hline
\end{tabular}

Berdasarkan tabel di atas, dapat diketahui bahwa pada saat pretest RA tidak mampu mengucapkan nama benda dari ketujuh mainan yang diberikan. Sedangkan setelah diberikan penerapan PECS dapat terlihat perubahan kemampuan berbicara ekspresif secara signifikan, yaitu RA mampu menyebutkan enam mainan yang diberikan secara spontan, jelas, dan mandiri. Sehingga dapat dikatakan bahwa HO ditolak dan Ha diterima, artinya penerapan Picture Exchange Communication System (PECS) efektif dalam meningkatkan kemampuan berbicara ekspresif pada anak down syndrome. 


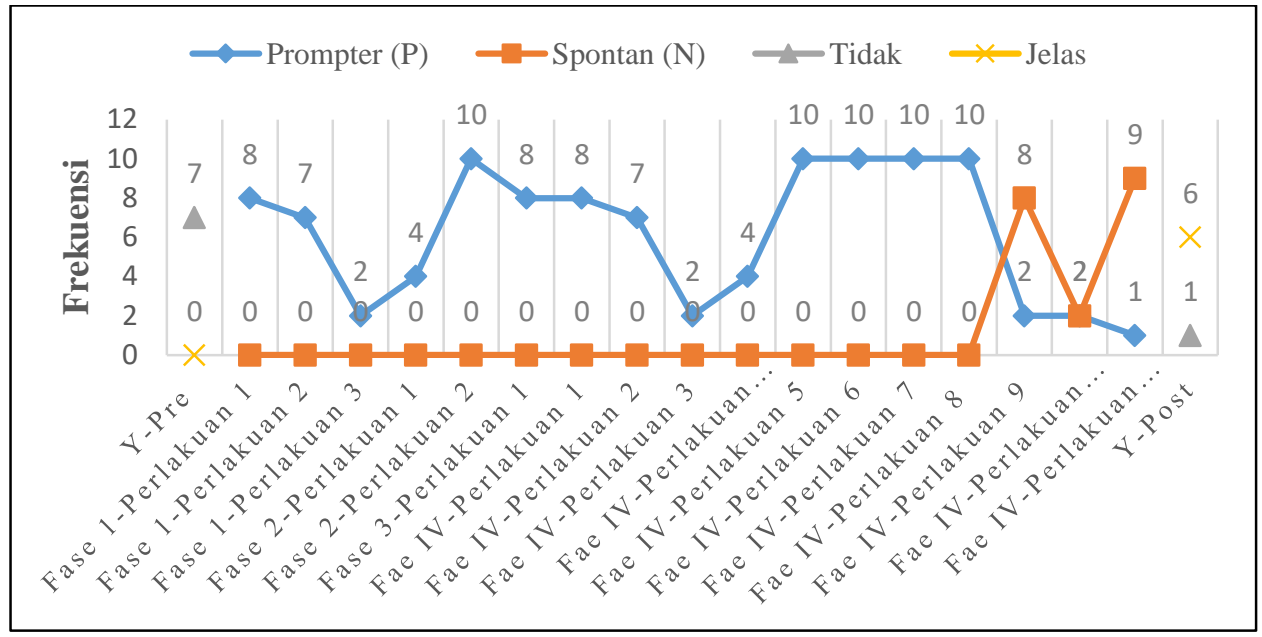

Grafik 1. Penerapan PECS

Berdasarkan grafik 1 di atas RA diberikan tiga kali perlakuan pada fase I, yaitu perlakuan pertama menggunakan prompter sebanyak enam kali pada percobaan satu sampai empat dan secara spontan empat kali pada percobaan lima sampai 10. Perlakuan kedua, responden sudah mampu melakukan 10 kali percobaan secara spontan. RA sudah mampu melewati fase I dengan dua kali perlakuan, namun untuk melihat konsistensi memahami pola komunikasi fase I RA kembali diberikan perlakuan ketiga. Perlakuan ketiga menggunakan prompter sebanyak dua kali pada percobaan satu sampai dua dan secara spontan delapan kali pada percobaan tiga sampai 10. RA sudah mampu memahami dengan baik pola komunikasi fase I, yaitu ketika menginginkan reinforcement yang diinginkan RA harus mengambil dan menukarkan kartu gambar yang sesuai. Reinforcement yang diinginkan RA pada fase I, yaitu:

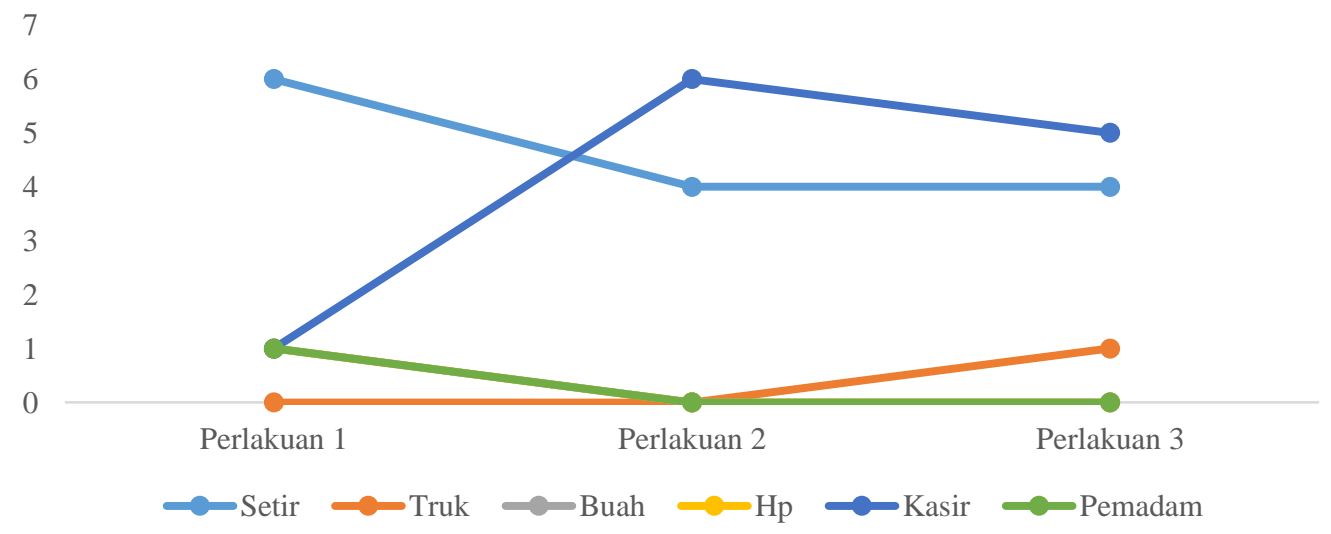

Grafik 2. Reinforcement Fase I

Berdasarkan grafik 2 di atas dapat kita ketahui bahwa pada perlakuan 1, RA menginginkan reinforcement setir sebanyak enam kali, buah satu kali, Hp satu kali, kasir satu kali, dan pemadam 1 kali. RA selalu menerima reinforcement yang ditukarkan. Pada percobaan kedua RA protes ketika reinforcement diminta kembali, namun pada percobaan satu, tiga sampai 10 RA tidak protes. RA mampu menukarkan kartu gambar sebanyak enam kali percobaan secara mandiri, namun belum mampu berhasil sebanyak $80 \%$ sehingga harus mengulang kembali. Perlakuan 2 RA menginginkan reinforcement setir 
sebanyak empat kali dan kasir enam kali. RA selalu menerima reinforcement yang ditukarkan, namun RA protes ketika diminta untuk dikembalikan pada percobaan kelima.

RA sudah mampu melakukan tukar kartu gambar sebanyak 10 kali secara mandiri pada perlakuan dua, namun RA kembali mengulang fase satu dengan tujuan melihat konsisten RA memahami fase satu. Perlakuan 3 RA menginginkan reinforcement setir sebanyak empat kali, truk satu kali, dan pemadam lima kali. RA selalu menerima reinforcement yang diberikan, namun RA protes ketika diminta untuk dikembalikan pada percobaan satu, dua, empat, dan enam. RA sudah mampu menukarkan kartu gambar sebanyak delapan kali percobaan atau $80 \%$ secara mandiri, sehingga mampu melewati fase I.

Berdasarkan grafik 1 di atas RA diberikan dua kali perlakuan pada fase II, yaitu perlakuan pertama menggunakan prompter sebanyak tiga kali. RA melakukan percobaan satu sampai tiga dengan jarak 2 meter. RA hanya mampu melakukan tiga kali percobaan dari 10 kali percobaan karena mengantuk. Perlakuan kedua RA sudah mampu melakukan 10 kali percobaan secara spontan dan mandiri dengan jarak 2 meter pada percobaan satu sampai lima. 4 meter pada percobaan keenam, 6 meter pada percobaan tujuh sampai sembilan, 8 meter pada percobaan 10 .

Fase II mengajarkan pola komunikasi menggunakan jarak dengan tujuan agar RA belajar bahwa mainan yang diinginkan tidak selalu berada di dekatnya. RA sudah mampu memahami dengan baik pola komunikasi fase II, yaitu ketika menginginkan reinforcement yang diinginkan RA harus berjalan mengambil dan menukarkan kartu gambar yang sesuai. Reinforcement yang diinginkan RA pada fase II, yaitu:

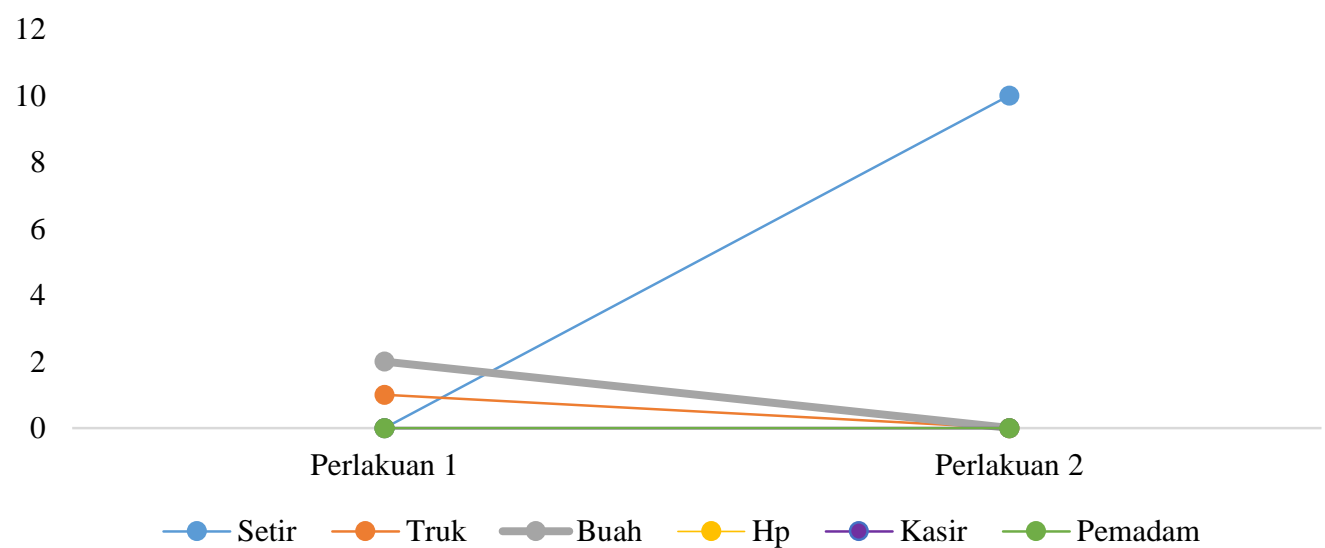

Grafik 3. Reinforcement Fase II

Berdasarkan grafik 3 di atas dapat kita ketahui bahwa pada perlakuan 1, RA menginginkan reinforcement truk sebanyak satu kali dan buah dua kali. RA selalu menerima reinforcement yang ditukarkan tanpa protes. Pada percobaan kedua RA protes ketika reinforcement diminta kembali, namun pada percobaan tiga RA tidak protes.

RA hanya mampu menukarkan kartu gambar sebanyak tiga kali percobaan secara mandiri, namun belum mampu berhasil sebanyak $80 \%$ sehingga harus mengulang kembali fase II. Perlakuan kedua RA hanya menginginkan reinforcement setir. RA selalu menerima barang yang ditukarkan, dan tidak protes ketika mainan dikembalikan. RA mampu 
melakukan 10 kali percobaan secara mandiri atau melewati minimal $80 \%$ tingkat keberhasilan sehingga berhasil melewati fase II.

Berdasarkan grafik 1 di atas RA hanya diberikan satu kali perlakuan pada fase III, yaitu perlakuan pertama RA sudah mampu melakukan 10 kali percobaan secara spontan dan mandiri. Fase III mengajarkan pola komunikasi dengan melakukan diskriminasi reinforcement yang diinginkan dan tidak diinginkan. RA sudah mampu memahami dengan baik pola komunikasi fase III. RA sudah mampu melakukan diskriminasi mainan dengan hanya mengambil kartu gambar yang diinginkan dan mengabaikan kartu gambar yang tidak diinginkan. Reinforcement yang diinginkan RA pada fase III, yaitu:

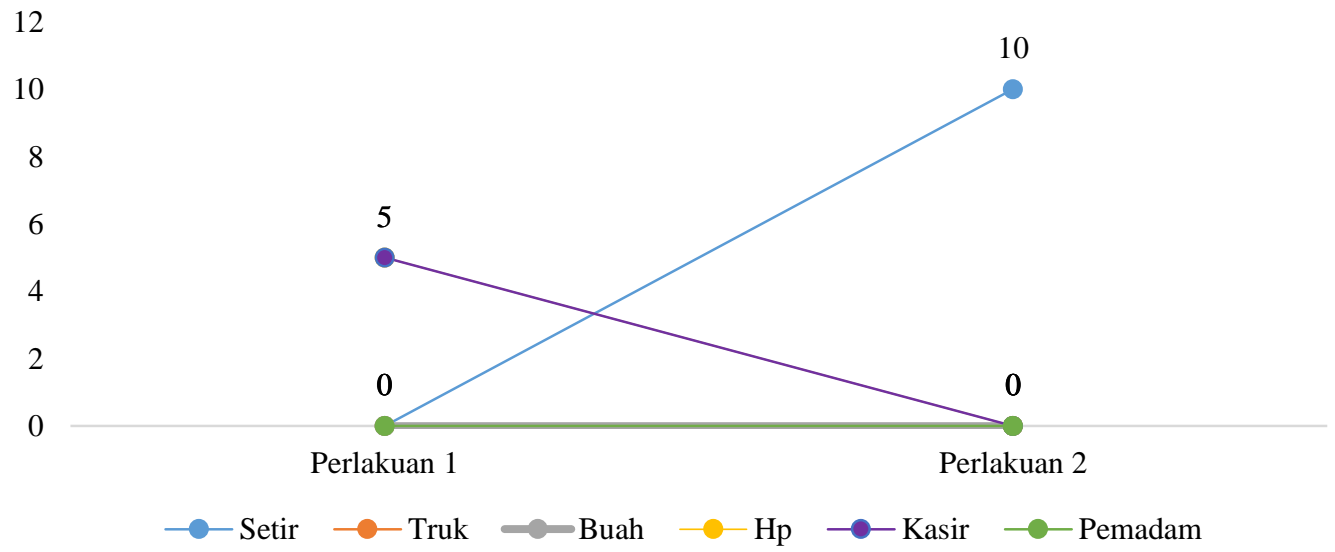

Grafik 4. Reinforcement Fase III

Berdasarkan grafik 4 di atas dapat kita ketahui bahwa, RA hanya mampu melakukan satu kali perlakuan. RA menginginkan reinforcement buah sebanyak dua kali, Hp lima kali, dan kasir tiga kali. RA selalu menerima reinforcement yang ditukarkan, dan tidak protes ketika mainan dikembalikan. RA mampu melakukan 10 kali percobaan secara mandiri atau melewati minimal $80 \%$ tingkat keberhasilan sehingga berhasil melewati fase III.

Berdasarkan grafik 1 di atas RA diberikan 11 kali perlakuan pada fase IV, yaitu perlakuan pertama sampai keempat RA tidak mampu melakukan 10 kali percobaan disetiap perlakuan dan menggunakan prompter. Perlakuan pertama RA hanya mampu melakukan delapan kali percobaan dengan bantuan prompter. Perlakuan kedua RA hanya mampu melakukan tujuh kali percobaan dengan bantuan prompter. Perlakuan ketiga RA hanya mampu melakukan dua kali percobaan dengan bantuan prompter. Perlakuan keempat RA hanya mampu melakukan empat kali percobaan dengan bantuan prompter.

RA tidak mampu melakukan 10 kali percobaan setiap perlakuan karena RA masih lebih memilih diam dan menunjuk-nunjuk ketika diminta mengucapkan reinforcement yang diinginkan. RA sudah mampu melakukan 10 kali percobaan setiap sesi pada perlakuan lima sampai 11, kecuali perlakuan 10. Perlakuan lima sampai delapan RA mampu melakukan 10 kali percobaan dengan menggunakan bantuan prompter. Perlakuan sembilan RA mampu melakukan delapan kali secara spontan dan dua kali dengan bantuan prompter pada percobaan tiga dan enam.

Perlakuan 10 RA hanya mampu melakukan dua kali percobaan dengan bantuan prompter dan dua kali secara spontan pada percobaan dua dan tiga. RA hanya mampu 
melakukan empat kali percobaan karena mengantuk sehingga RA hanya diam ketika diberikan instruksi oleh terapis. Perlakuan 11 RA hanya mampu melakukan satu kali menggunakan bantuan prompter pada percobaan dua dan sembilan kali secara spontan.

Fase IV mengajarkan pola komunikasi melatih kemampuan berbicara dengan menyebutkan "saya mau..." sambil menyebutkan reinforcement yang diinginkan. Kemampuan berbicara RA mulai terlihat dari perlakuan ketujuh. RA sudah mampu mengucapkan "saya" secara spontan dan mandiri walaupun masih menggunakan bantuan prompter mengucapkan "mau" dan mainan yang dipilih. Perlakuan kesembilan RA sudah mampu mengucapkan "saya mau" secara spontan dan mandiri.

Perlakuan 11 RA mampu mengucapkan "saya mau..." dengan reinforcement yang diinginkan secara spontan dan mandiri, kecuali pemadam. RA hanya mampu mengucapkan "pe...dam" dan dibantu menyebutkan " $m a$ " oleh terapis. RA sudah mampu memahami pola komunikasi fase IV, yaitu mengucapkan kartu gambar yang diambil untuk mendapatkan reinforcement yang diinginkan. Reinforcement yang diinginkan RA pada fase IV, yaitu:

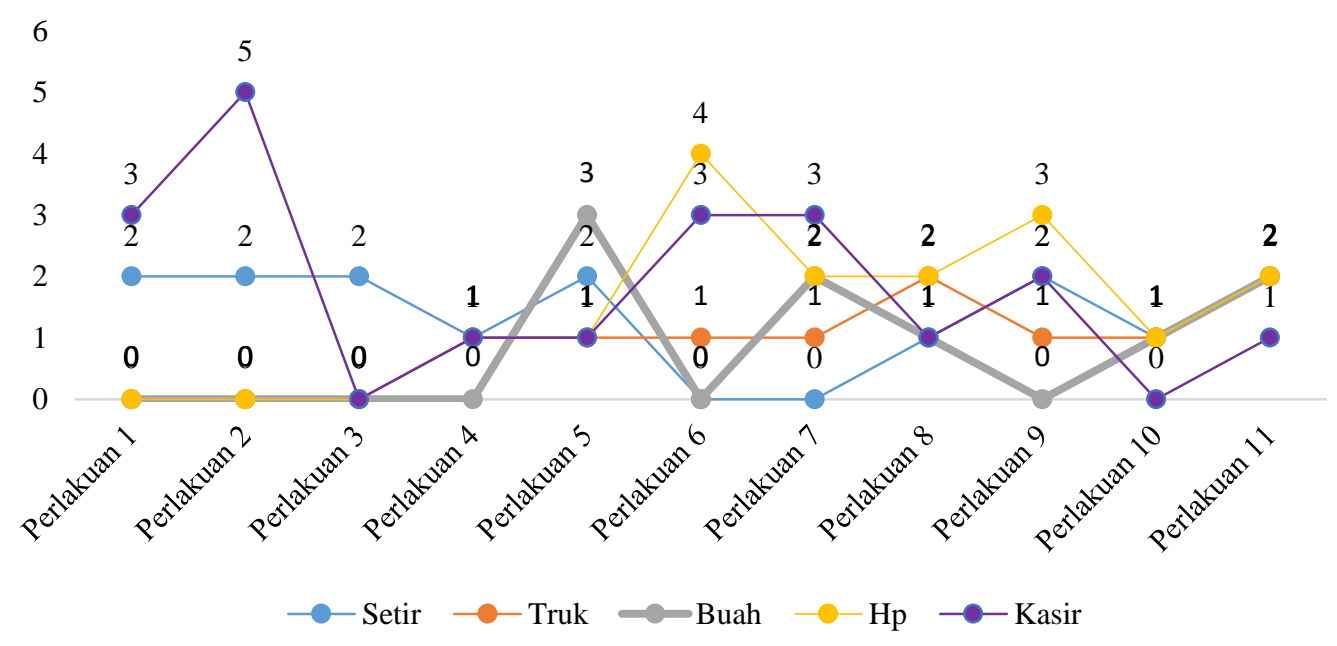

Grafik 5. Reinforcement Fase IV

Berdasarkan grafik 5 di atas dapat kita ketahui bahwa RA melakukan 11 kali perlakuan. Perlakuan 1 RA menginginkan reinforcement setir sebanyak dua kali, Hp tiga kali, dan pemadam dua kali. RA selalu menerima reinforcement yang ditukarkan, dan tidak protes ketika dikembalikan. RA hanya mampu melakukan delapan kali percobaan dengan bantuan prompter, sehingga belum berhasil mencapai minimal $80 \%$ keberhasilan secara mandiri dan RA harus mengulang kembali fase IV.

Perlakuan 2 RA menginginkan reinforcement setir sebanyak dua kali dan kasir lima kali. RA selalu menerima reinforcement yang ditukarkan, dan tidak protes ketika dikembalikan. RA belum berhasil mencapai minimal 80\% keberhasilan secara mandiri, sehingga harus mengulang kembali fase IV. Perlakuan 3 RA hanya menginginkan reinforcement setir sebanyak dua kali. RA selalu menerima reinforcement yang ditukarkan, dan tidak protes ketika dikembalikan. RA belum berhasil mencapai minimal $80 \%$ keberhasilan secara mandiri, sehingga harus mengulang kembali fase IV.

Perlakuan 4 RA menginginkan reinforcement setir sebanyak satu kali, truk satu kali, Hp satu kali, dan kasir satu kali serta RA selalu menerima reinforcement yang 
ditukarkan, dan tidak protes ketika mainan dikembalikan. RA belum berhasil mencapai minimal $80 \%$ keberhasilan secara mandiri, sehingga harus mengulang kembali fase IV. Perlakuan 5 RA menginginkan reinforcement setir sebanyak dua kali, truk satu kali, buah tiga kali, Hp satu kali, kasir satu kali, dan pemadam satu kali. RA menolak menerima reinforcement enam dan delapan, kemudian protes pada percobaan satu dan lima ketika reinforcement dikembalikan. RA belum berhasil mencapai minimal $80 \%$ keberhasilan secara mandiri, sehingga harus mengulang kembali fase IV.

Perlakuan 6 RA menginginkan reinforcement truk sebanyak satu kali, Hp empat kali, kasir tiga kali, dan pemadam dua kali serta RA menolak menerima reinforcement dua, namun tidak protes ketika reinforcement dikembalikan. RA belum berhasil mencapai minimal 80\% keberhasilan secara mandiri, sehingga harus mengulang kembali fase IV. Perlakuan 7 RA menginginkan reinforcement truk sebanyak satu kali, buah satu kali, Hp dua kali, kasir tiga kali, dan pemadam dua kali serta RA selalu menerima reinforcement yang ditukarkan, dan tidak protes ketika dikembalikan. RA belum berhasil mencapai minimal 80\% keberhasilan secara mandiri, sehingga harus mengulang kembali fase IV.

Perlakuan 8 RA menginginkan reinforcement setir sebanyak satu kali, truk dua kali, buah satu kali, Hp dua kali, kasir satu kali, dan pemadam dua kali. RA selalu menerima reinforcement yang ditukarkan, dan tidak protes ketika dikembalikan. RA belum berhasil mencapai minimal 80\% keberhasilan secara mandiri, sehingga harus mengulang kembali fase IV.

Perlakuan 9 RA menginginkan reinforcement setir sebanyak dua kali, truk satu kali, Hp tiga kali, kasir dua kali, dan pemadam dua kali. RA selalu menerima reinforcement yang ditukarkan, dan tidak protes ketika dikembalikan. RA belum berhasil mencapai minimal 80\% keberhasilan secara mandiri, sehingga harus mengulang kembali fase IV.

Perlakuan 10 RA menginginkan reinforcement setir sebanyak satu kali, buah satu kali, Hp satu kali, dan pemadam satu kali. RA selalu menerima barang yang ditukarkan, dan tidak protes ketika mainan dikembalikan. RA belum berhasil mencapai minimal $80 \%$ keberhasilan secara mandiri, sehingga harus mengulang kembali fase IV.

Perlakuan 11 RA menginginkan reinforcement setir sebanyak dua kali, buah dua kali, Hp dua kali, kasir satu kali, dan pemadam satu kali. RA selalu menerima barang yang ditukarkan, dan tidak protes ketika mainan dikembalikan. RA sudah mampu melakukan 10 kali percobaan secara spontan dan mandiri, sehingga sudah berhasil mencapai minimal $80 \%$ keberhasilan secara spontan dan mandiri.

\section{Pembahasan}

Penerapan PECS diberikan setelah RA diberikan pretest. Penerapan PECS dilakukan sebanyak 17 kali perlakuan dari fase I sampai IV. Fase I tiga kali perlakuan, fase II dua kali perlakuan, fase III satu kali perlakuan, dan fase IV 11 kali perlakuan. RA mampu dengan cepat memahami pola komunikasi fase I sampai III, hal ini terlihat dari jumlah perlakuan setiap fase.

Fase I RA sudah mampu memahami pola komunikasi dengan mengambil kartu gambar, menempelkan kartu gambar, dan menukarkan kartu gambar ke terapis. Fase II RA sudah mampu memahami pola komunikasi dengan berjarak dan belajar bahwa tidak selamanya benda yang diinginkan berada di sekitarnya, sehingga RA harus berjalan untuk mendapatkan yang diinginkan. Fase III RA sudah mampu memahami pola komunikasi 
dengan melakukan diskriminasi reinforcement. RA sudah mampu mengambil mainan sesuai dengan yang diinginkan. Fase IV RA sudah mampu memahami pola komunikasi dengan menyebutkan reinforcement yang diinginkan.

Berdasarkan hasil penelitian yang dilakukan oleh peneliti ditinjau dari perubahan yang signifikan kemampuan berbicara ekspresif pada hasil pretest RA tidak mampu mengucapkan sama sekali tujuh mainan dan hasil posttest RA mampu mengucapkan enam mainan, sehingga dapat dikatakan hipotesis dalam penelitian ini diterima. Hal ini membuktikan bahwa penerapan PECS yang diberikan pada satu anak down syndrome efektif dalam meningkatkan kemampuan berbicara. Seniati, Yulianto, dan Setiabudi (2015) mengemukakan bahwa apabila terdapat perbedaan antara skor pretest dan posttest, maka rancangan eksperimen memiliki efek.

Hasil penelitian ini sejalan dengan Barbosa, Oliveira, Antão, Crocetta, Guarnieri, Antunes, Arab, Massetti, Bezerra, Monteiro, dan Abreu (2018) juga mengemukakan bahwa PECS merupakan salah satu alat komunikasi yang digunakan dan berada pada urutan kedua setelah SGDs yang efektif digunakan untuk membantu anak down syndrome berkomunikasi. Selain itu, hasil penelitian Suchowierska, Rupińska, dan Bondy (2013) mengemukakan bahwa PECS berfungsi untuk mengajarkan anak berkomunikasi secara efektif dan efisien, mengurangi perilaku bermasalah, dan meningkatkan perkembangan bicara. PECS efektif untuk membantu anak-anak berkomunikasi, karena menurut hasil penelitian Preston dan Carter (2009) mengemukakan bahwa PECS lebih mudah dipahami dan membantu individu yang memiliki sedikit kosa kata ataupun yang belum memiliki kosa kata dalam berkomunikasi.

Selain itu, Hart dan Banda (2010) juga melakukan penelitian kepada 13 siswa yang memiliki gangguan komunikasi hasilnya, yaitu PECS tidak hanya meningkatkan kemampuan berbicara, namun membantu meningkatkan perilaku sosial, dan mengurangi masalah perilaku. Hasil penelitian di atas sejalan dengan hasil temuan peneliti, dimana RA mulai mampu berkomunikasi dengan mengatakan "saya mau..." ketika mengininkan mainan, selain itu perilaku bermasalah responden juga berkurang seperti marah-marah dan komunikasi non verbal terlihat menurun. Hal ini terlihat dari pemberian PECS fase IV dimana RA sudah mampu memahami pola komunikasi ketika menginginkan mainan RA memilih untuk menggunakan komunikasi verbal dibandingkan menggunakan baha nonverbal. Sehingga orang tua RA lebih mudah memahami keinginan RA dan perilaku marah-marah RA tidak muncul, karena apa yang diinginkan terpenuhi.

Hurlock (2008) mengemukakan bahwa terdapat sembilan faktor yang mempengaruhi kemampuan berbicara ekspresif, yaitu kesehatan, kecerdasan, keadaan sosial ekonomi, dan jenis kelamin. Kemudian keinginan berkomunikasi, dan urutan kelahiran, hubungan teman sebaya, dan kepribadian anak. Efektivitas penerapan PECS terhadap responden dapat ditinjau berdasarkan faktor-faktor di atas yang mempengaruhi kemampuan berbicara sesuai dengan keadaan di lapangan selama proses penelitian. Faktor-faktor yang mempengaruhi, yaitu kesehatan, jenis kelamin, keinginan berkomunikasi, dan kepribadian anak.

Faktor kesehatan, selama proses penelitian fator kesehatan sangat mendukung terlaksananya proses penelitian. Apabila RA sakit, maka proses penelitian tidak dilakukan. Selama proses penelitian RA sakit sebanyak empat kali dengan rentang waktu yang berbeda-beda dari dua hari sampai empat hari. Faktor inilah yang menyebabkan proses 
penelitian tidak dapat dilakukan secara intens atau setiap hari, sehingga proses penelitian lebih lama.

Faktor jenis kelamin, selama proses penelitian RA tidak terlalu aktif dalam berbicara. Memasuki fase IV RA memerlukan waktu lebih lama untuk mencapai $80 \%$ tingkat keberhasilan karena ketika diminta mengikuti terapis berbicara RA memilih untuk diam dan tidur di depan terapis. Hurlock (2008) mengemukakan bahwa anak laki-laki cenderung menggunakan kata yang pendek, tidak sesuai tata bahasa, dan kosakata yang sedikit ketiba berbicara.

Faktor keinginan berkomunikasi, selama proses penelitian keinginan berkomunikasi RA sangat tergantung pada suasana hati. Rentang waktu perlakuan PECS dapat berlangsung cepat atau lambat tergantung pada keinginan berkomunikasi. RA biasanya cepat melakukan perlakuan satu sampai 10 ketika dalam keadaan suasana hati yang baik, seperti tidur sebelum sesi pemberian PECS, tidak bermasalah dengan anggota keluarga yang lain, dan tidak kelelahan. Sebaliknya RA tidak ingin berkomunikasi atau mengikuti sesi pemberian PECS ketika memiliki suasana hati yang buruk, seperti mengantuk, kelelahan, dan memiliki masalah dengan anggota keluarga. Suasana hati yang buruk menyebabkan proses pemberian PECS lebih lama atau tidak dapat mencapai $10 \mathrm{kali}$ percobaan.

Alternatif peneliti dan team ketika RA memiliki suasana hati yang buruk, yaitu mengajak jalan-jalan di sekitar halaman rumah RA atau memberikan RA waktu bermain dengan mainan yang bukan reinforcement. Apabila alternatif yang dilakukan berhasil, maka RA mampu menyelesaikan 10 kali percobaan tapi selalu dibantu oleh prompter. Kemudian ketika tidak berhasil, maka sesi pemberian PECS berakhir.

Faktor kepribadian anak, selama proses penelitian RA merupakan anak yang ramah dan penyayang. Peneliti dan team tidak kesulitan untuk beradaptasi dengan RA. RA cepat akrab dengan peneliti dan team, dan mudah diajak bermain bersama, sehingga proses pemberian fase-fase awal tidak berlangsung lama dan RA cepat memahami pola komunikasi PECS. Faktor lain yang menyebabkan proses penerapan PECS lebih lama pada fase IV, yaitu RA dan keluarga ke luar daerah sehingga proses penelitian dihentikan selama empat hari. Penerapan PECS yang dilakukan dengan jeda waktu yang lama menyebabkan proses penelitian lebih lama dan progress kemampuan RA difase IV lebih lambat.

\section{SIMPULAN}

Berdasarkan hasil penelitian dan pembahasan diperolah bahwa, penerapan Picture Exchange Communication System (PECS) efektif dalam meningkatkan kemampuan berbicara ekspresif pada anak down syndrome. Hal ini ditunjukkan dengan adanya perbedaan hasil posttest yang meningkat dari hasil pretest setelah penerapan PECS. Hasil pretest menunjukkan responden tidak mampu mengucapkan tujuh mainan yang diberikan, namun setelah 17 kali pemberian responden mampu mengucapkan enam mainan yang diberikan. Responden mengalami peningkatan enam jumlah kosakata, yaitu setir, truk, buah, hp, kasir, dan laba-laba. 


\section{DAFTAR PUSTAKA}

Barbosa, R. T. de A., de Oliveira, A. S. B., de Lima Antão, J. Y. F., Crocetta, T. B., Guarnieri, R., Antunes, T. P. C., ... de Abreu, L. C. (2018). Augmentative and alternative communication in children with down's syndrome: A systematic review. BMC Pediatrics, 18(1), 1-16. https://doi.org/10.1186/s12887-018-1144-5.

Creswell, J. W. (2014). Research design: qualitative, quantitative, and mixed methods approaches. California: SAGE Publication.

Hart, S. L., \& Banda, D. R. (2010). Picture exchange communication system with individuals with developmental disabilities: A meta-analysis of single subject studies. Remedial and Special Education, 31(6), 476-488. https://doi.org/10.1177/0741932509338354.

Heryati, E., \& Ratnengsih, E. (2017). Penggunaan metode PECS (Picture Exchange Communication System) untuk meningkatkan kemampuan komunikasi anak autis. Pedagogia: Jurnal Ilmu Pendidikan, 15(1), 30. https://doi.org/10.17509/pedagogia.v15i1.6558

Hurlock. (2008). Psikologi perkembangan. Jakarta: Erlangga Press.

Indah, R. N. (2017). Gangguan berbahasa kajian pengantar. Malang: UIN MALIKI Press.

Irwanto, Wicaksono, H., Ariefa, A., \& Samosir, A. M. (2019). A-Z sindrom down. Surabaya: Airlangga University Press.

Kumin, L. I. K. (2003). Starting out: speech and language intervention for infants and toddlers with down syndrome. Down Syndrome. In Down Syndrome (pp. 393-406). https://doi.org/10.1002/0471227579.ch29

Latipun. (2008). Psikologi eksperimen. Malang: UMM Press.

Marder, L., \& Ní Cholmáin, C. (2006). Promoting language development for children with Down's syndrome. Current Paediatrics, 16(7), 495-500. https://doi.org/10.1016/j.cupe.2006.08.022

Mukhtar. (2013). Metode praktis penelitian deskriptif kualitatif. Jakarta Selatan: GP Press Group.

Preston, D., \& Carter, M. (2009). A review of the efficacy of the picture exchange communication system intervention. Journal of Autism and Developmental Disorders, 39(10), 1471-1486. https://doi.org/10.1007/s10803-009-0763-y

Rosalina, D. (2017). Pengaruh metode PECS (Picture Exchange Communication System) terhadap komunikasi nonverbal peserta didik autis di slbn pembina provinsi sulawesi selatan. Universitas Negeri Makassar.

Seniati, L., Yulianto, A., \& Setiabudi, B. (2015). Psikologi eksperimen. Jakarta: PT Indeks.

Suchowierska, M., Rupińska, M., \& Bondy, A. (2013). Picture Exchange Communication System ( PECS ): A short " tutorial " for the doctors. Postępy Nauk Medycznych, xxvi(1), 85-90.

Sugiyono. (2016). Metode penelitian pendidikan (pendekatan kuantitatif, kualitatif dan $R \& D)$. Alfabeta.

Sunanto, J., Takeuchi, K., \& Nakata, H. (2005). Pengantar penelitian dengan subjek tunggal. Japan: Center of Research on International Cooperation in Educational Development (CRICED) University of Tsukuba. 
Vistasari, R., \& Patria, B. (2019). Program PECS (Picture Exchange Communication System) untuk meningkatkan kemampuan berbicara terstruktur pada anak autis. Gadjah Mada Journal of Professional Psychology (GamaJPP), 5(1), 94. https://doi.org/10.22146/gamajpp.48590.

Wardah. (2019). Antara fakta dan harapan sindrom down. Jakarta: Kementrian Kesehatan RI Pusat data dan Infomasi. 